\title{
Retrospective identification of human cases of West Nile virus infection in Austria (2009 to 2010) by serological differentiation from Usutu and other flavivirus infections
}

K Stiasny (karin.stiasny@meduniwien.ac.at) ${ }^{1,2}$, S W Aberle ${ }^{1,2}$, F X Heinz ${ }^{1}$

1. Department of Virology, Medical University of Vienna, Vienna, Austria

2. These authors contributed equally to this work

Citation style for this article:

Stiasny K, Aberle SW, Heinz FX. Retrospective identification of human cases of West Nile virus infection in Austria (2009 to 2010) by serological differentiation from Usutu and other flavivirus infections. Euro Surveill. 2013;18(43):pii=20614. Available online: http://www.eurosurveillance.org/ViewArticle.aspx?Articleld=20614

There is increasing evidence for the spread of West Nile virus (WNV) in southern, eastern and central Europe. In parallel, another flavivirus, the antigenically closely related Usutu virus, was introduced from Africa and first detected in Austria (2001), followed by Spain (2003), Hungary (2005), Italy (2006), Switzerland (2006) and Germany (2007). In Austria, human WNV infections have not previously been documented, although the virus was isolated from birds and detected in mosquitoes in 2008 and 2009. We therefore conducted a retrospective search for human cases of WNV infection using serum and cerebrospinal fluid samples collected from patients with central nervous system (CNS) disease in the summers of 2009, 2010 and 2011. Although all samples were negative for WNV by polymerase chain reaction, quantitative evaluation of standardised antibody assays with purified flavivirus antigens (including Usutu virus, which cross-reacts with WNV even in neutralisation assays) provided serological evidence for three autochthonous WNV infections in Austria: two in 2009 and one in 2010. Our data highlight the importance of raising awareness of WNV infections in Austria and neighbouring countries and suggest including testing for this infection in routine diagnostic practice of CNS diseases.

\section{Introduction}

West Nile virus (WNV) is a mosquito-borne member of the genus Flavivirus (Family Flaviviridae) [1], which has a wide geographical distribution and is found in regions of Africa, Asia, Australia, Europe and the Americas [2]. Although most human infections are subclinical or result in mild febrile disease, about 1 in 150 infected individuals develop severe neurological symptoms with a potentially lethal outcome [3]. There is evidence for an increase and spread of WNV infections in Europe, especially in south-eastern countries [4,5]. This was most noticeable in the Central Macedonian Region of Greece in 2010, where human WNV infections $(n=262)$ resulted in 197 neurological cases and 35 deaths [6]. This was the third-largest human WNV outbreak in the World Health Organization (WHO) European region, after those in Romania in 1996 (Bucharest region; 393 cases and 17 deaths) and Russia in 1999 (Volgograd region; 826 cases and 40 deaths) [2]. In addition to such locally restricted epidemics, intensified surveillance programmes have documented the presence of the virus in animals and substantial numbers of human infections have been documented since the beginning of the 2013 transmission season in Greece $(n=86)$, Hungary $(n=29)$, Italy $(n=66)$, Romania $(n=22)$, Croatia $(n=16)$, Serbia $(n=260)$ and Russia $(n=177)$ as well as sporadic human infections in Bosnia and Herzegovina $(n=3)$, former Yugoslav Republic of Macedonia $(n=1)$ and Montenegro $(n=2)$, as of 10 October 2013 [5]. Both genetic lineages of WNV (I and II) have been associated with human disease and new introductions (most likely through migratory birds), as well as overwintering of the virus in mosquitoes, have been observed [4].

Similar to the situation with WNV, there is increasing documentation of human and animal Usutu virus (USUV) infections in Europe since the first reports of its introduction in Austria in birds in 2001 [7], with virus isolation and/or serologically confirmed infections in animals or humans in Hungary, Italy, Spain, Switzerland and Germany [8]. Although human USUV infections are believed to take a mild or asymptomatic course, impairment of neurological function has also been described in two persons with underlying diseases [8].

Since WNV viraemia is short-lived, the amount of virus in serum and cerebrospinal fluid (CSF) samples has frequently dropped below levels detectable by polymerase chain reaction (PCR) when central nervous system (CNS) symptoms start and patients are hospitalised [9]. Therefore laboratory diagnosis usually has to rely 


\section{FIGURE 1}

Dendrogram by percentage amino acid identity of the envelope protein $\mathrm{E}$ from various flaviviruses

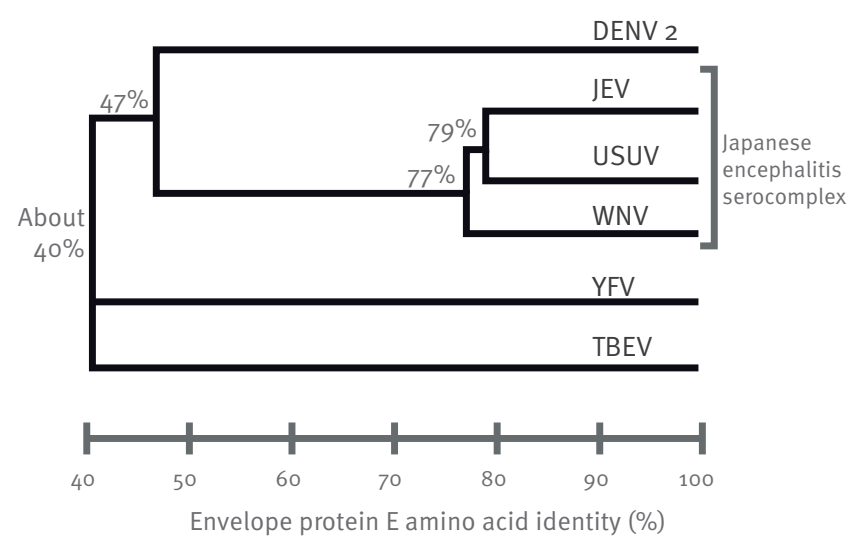

DENV 2: dengue virus type 2 (strain 16681; GenBank accession number NC_001474)

JEV: Japanese encephalitis virus (strain Nakayama; GenBank accession number U44966)

USUV: Usutu virus (strain SAAR;

GenBank accession number AY453412)

WNV: West Nile virus (strain NY99;

GenBank accession number DQ211652)

YFV: yellow fever virus (strain 17D;

GenBank accession number Xo3700)

TBEV: tick-borne encephalitis virus (strain Neudoerfl; GenBank accession number U27495)

on the detection of specific antibodies [10]. However, the results of these assays may be biased by crossreactive antibodies induced by other autochthonous or imported flavivirus infections and/or vaccinations. These include tick-borne encephalitis virus (TBEV), which is endemic in large parts of Europe, with high vaccination rates in certain countries $(85 \%$ in Austria [11]), dengue viruses (DENVs), yellow fever virus (YFV) (travel vaccination), Japanese encephalitis virus (JEV) (travel vaccination) and USUV. The problem of crossreactivity is most pronounced with viruses belonging to the same flavivirus serocomplex. WNV - like USUV - is a member of the Japanese encephalitis (JE) serocompex $[1,12]$ : these viruses have approximately $80 \%$ identical amino acids in the envelope protein $\mathrm{E}$ (Figure 1), the major target of neutralising antibodies. With such closely related viruses, cross-reactivities are not only observed in enzyme immunoassays but also in virus neutralisation assays [12] that are proposed for discriminating between different flavivirus infections [10]. Viruses of different serocomplexes (e.g. TBEV, DENV, YFV) have only about $40 \%$ identical amino acids in E (Figure 1). Cross-neutralisation is usually not observed in these cases [12], but cross-reactivity is still detectable in enzyme-linked immunoassay (ELISA) and haemagglutination inhibition assays [13].

Austria is adjacent to countries that have reported human cases of WNV infection (Italy and Balkan countries in the south as well as Hungary in the east $[4,5]$ ) and the virus was isolated in the eastern part of Austria from birds of prey in 2008 and 2009 [14] and overwintering mosquitoes (2008-09; Norbert Nowotny, personal communication, September 2012). Human cases, however, have not been documented in Austria to date. We therefore aimed to conduct a retrospective search for human cases of WNV infection by analysing serum and CSF samples from patients who had been sent to our department in the summer of 2009, 2010 and 2011 with suspected TBE or other CNS infections, but whose samples did not yield laboratory evidence of a recent viral infection. For this purpose, we designed quantitative serological methods that - even in the presence of cross-reactive antibodies - allowed us to discriminate between infections with closely related flaviviruses of the JE serocomplex.

\section{Methods}

\section{Human sera}

We analysed patients' serum and CSF samples that had been submitted to the Department of Virology, Medical University of Vienna during 2009 to 2011 for virological laboratory diagnosis of CNS infections (most of them being suspected cases of TBE). We used the following criteria for the selection of patient samples: (i) time window of August and September for sample collection date, because most of the WNV infections in other European countries have been reported in these months [15]; (ii) age more than 70 years, because elderly people are more likely to develop CNS symptoms than younger people [15]; and (iii) availability of serum and, if possible CSF, taken upon hospitalisation.

The controls used in the quantitative IgM and IgG ELISAs were sera from WNV-, USUV- and JEV-infected people obtained from the following: (i) an external assay quality control study performed by the European Network for Diagnostics of Imported Viral Diseases, ENIVD (WNV, USUV); (ii) a commercially available JE Detect IgM Capture ELISA from InBios, Seattle, WA, United States; and (iii) TBE cases confirmed at the Department.

All samples were tested with the approval of the local ethics committee.

\section{West Nile virus IgM screening}

For the screening of WNV-specific IgM antibodies in patient sera, the commercial WN Detect IgM Capture ELISA (InBios; Seattle, WA, United States) was used. 
Patient information of cases of West Nile virus infection, Austria, 2009-10 (n=3)

\begin{tabular}{|c|c|c|c|}
\hline Patient information & Case 1 (2009) & Case 2 (2010) & Case 3 (2009) \\
\hline Age group in years at symptom onset & $80-85$ & $75-80$ & $10-15$ \\
\hline Place of residence & South of Vienna & Vienna & Vienna \\
\hline $\begin{array}{l}\text { Stay outside place of residence } \\
\text { during incubation period }\end{array}$ & No & No & No \\
\hline Clinical picture & Fever $\left(38.5^{\circ} \mathrm{C}\right)$; encephalitis & Fever $\left(39.5^{\circ} \mathrm{C}\right)$; meningitis & $\begin{array}{l}\text { Fever }\left(39.4^{\circ} \mathrm{C}\right) \text {; exanthema; } \\
\text { no neurological symptoms }\end{array}$ \\
\hline TBE vaccination & No record & $\begin{array}{l}\text { Irregular vaccination schedule } \\
\text { Last vaccination >10 years } \\
\text { before hospitalisation }\end{array}$ & $\begin{array}{c}\text { Regular vaccination schedule } \\
\text { Last vaccination about } 3 \text { years } \\
\text { before hosptitalisation }\end{array}$ \\
\hline Samples ${ }^{a}$ & $\begin{array}{l}\text { Day o: serum and CSF } \\
\text { Day 879: serum }\end{array}$ & Day o: serum and CSF & $\begin{array}{l}\text { Day 0: serum } \\
\text { Day 83: serum } \\
\text { Day 111: serum }\end{array}$ \\
\hline
\end{tabular}

TBE: tick-borne encephalitis.

a Day o: sample obtained upon hospitalisation of the patient.

Quantitative IgM and IgG determination for West Nile virus and closely related flaviviruses IgM and IgG antibody titres were determined by ELISA using purified formalin-inactivated preparations $[16,17]$ of WNV (strain NY99; GenBank accession number DQ211652), USUV (strain SAAR; GenBank accession number AY453412), JEV (strain Beijing; GenBank accession number L48961) and TBEV (strain Neudoerfl; GenBank accession number U27495) as antigens ( $25 \mathrm{ng} /$ well) directly coated to the solid phase of non-treated microtitre plates (Nunc, Thermo Fisher Scientific, Waltham, MA, United States). After blocking with phosphate-buffered saline containing $2 \%$ lamb serum and $2 \%$ Tween 20 for 30 minutes at $37^{\circ} \mathrm{C}$, 10 -fold serial dilutions of sera (starting dilution 1:100) in blocking buffer were added and incubated for 1 hour at $37^{\circ} \mathrm{C}$. In the case of the IgM ELISA, sera were pre-incubated with rheumatoid-factor-IgG-absorbent (Siemens Healthcare Diagnostics GmbH, Eschborn, Germany). Biotin-labelled goat anti-human IgM or IgG (Pierce Protein Biology Products, Thermo Fisher Scientific, Waltham, MA, United States) together with Streptavidin-Peroxidase (Sigma-Aldrich Inc., St. Louis, MO, United States) was used for detection.

Titration curves were established using the absorbance values at $490 \mathrm{~nm}$ and fitted by a four-parameter logistic regression (GraphPad Prism 5.0). Titres were then determined by calculating the intersection of the fitted curve with the cut-off, which was defined as the threefold of the mean absorbance value obtained with eight flavivirus antibody-negative sera.

\section{Determing IgG avidity}

As an additional marker for recent infection, we determined the relative avidities of WNV-specific IgG antibodies. For this purpose, we used the same $\lg G$ ELISA as described above, except for a wash step after serum incubation in which either $6 \mathrm{M}$ urea or phosphate-buffered saline $\mathrm{pH} 7.4$ was added for $5 \mathrm{~min}$ utes at room temperature $[17,18]$. The dilution curves were fitted using a four-parameter logistic regression (GraphPad Prism 5.0) and the titres were determined at an absorbance value of $0.5(490 \mathrm{~nm})$. The avidity of each serum was calculated with the following formula: Avidity $(\%)=($ titre with urea/titre without urea) $\times 100$.

\section{Neutralisation test}

Serial twofold dilutions (starting dilution 1:10) of heatinactivated sera (duplicates) were mixed with an equal volume of virus dilution (containing $20-40 \mathrm{TCID}_{50}(50 \%$ tissue culture infective dose) of WNV strain NY99) and incubated for one hour at $37^{\circ} \mathrm{C}$. Vero cells were added and incubation was continued for four to six days. Presence of virus in the supernatant was assessed by the occurrence of cytopathic effects. Neutralisation test (NT) titres $\geq 20$ were considered positive.

\section{Detection of West Nile virus RNA}

WNV RNA was extracted from $200 \mu \mathrm{l}$ serum or CSF and eluted in $50 \mu \mathrm{l}$ using the automated NucliSENS easyMAG extractor (bioMérieux, Marcy l'Etoile, France). A real-time TaqMan PCR for the detection of WN virus lineages 1 and 2 with primers and probe located within the conserved WN virus 3'-noncoding region was used, as described elsewhere [19]. The PCR was controlled using sera from an external proficiency panel as standards [20].

\section{Results}

Samples of 110 patients with neurological symptoms and unknown aetiology were selected for this 
West Nile virus serology of sera obtained upon hospitalisation (day 0) and follow-up samples from human cases of West Nile virus infection, Austria, 2009-10 $(n=3)$

$\lg M$
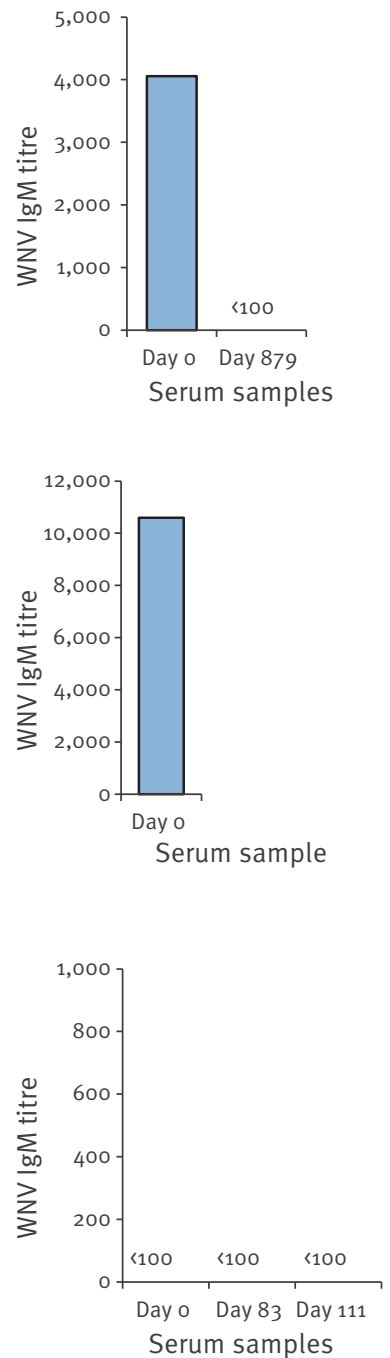

$\lg G$
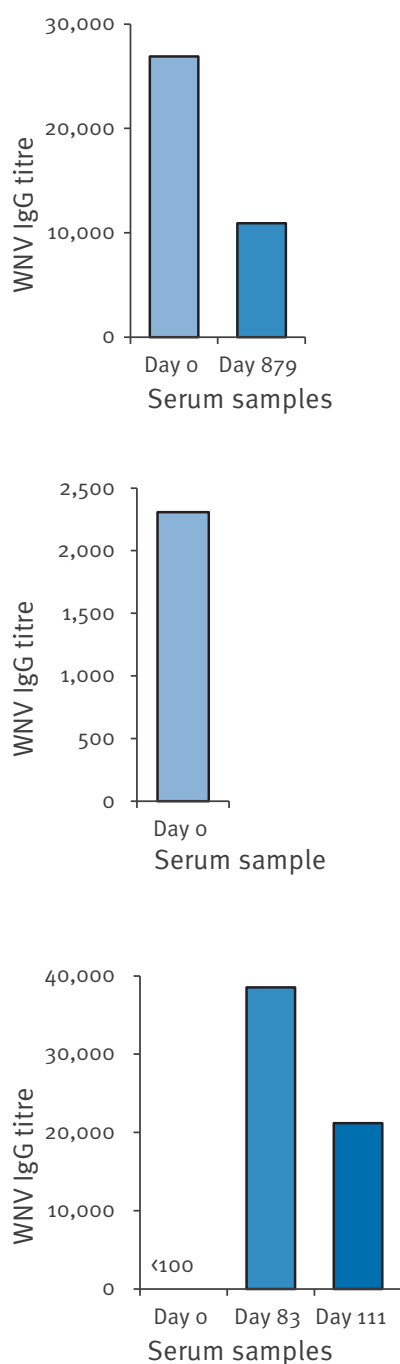

IgG avidity
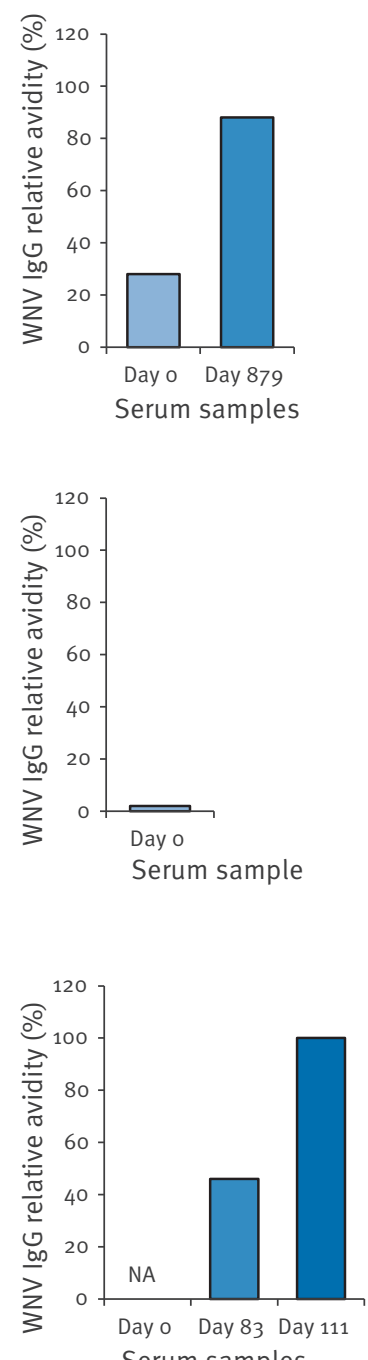

NT
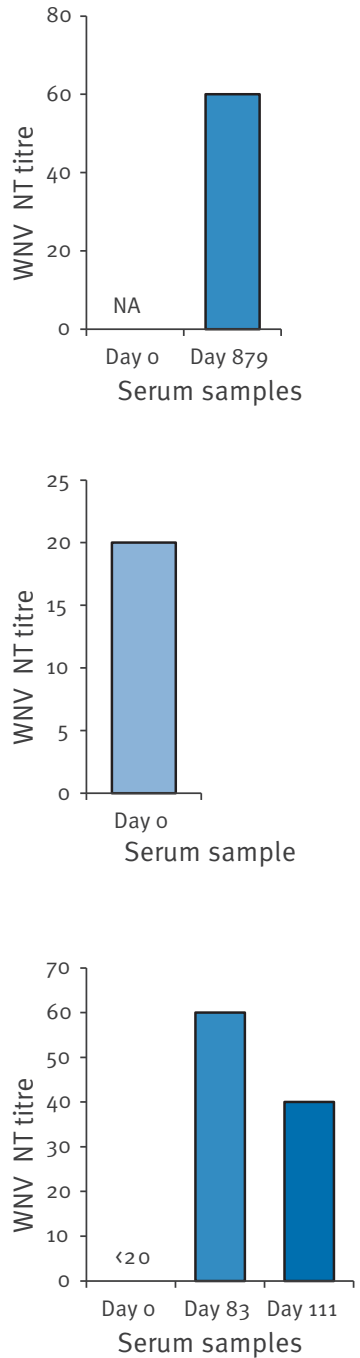

NA: not analysed; NT: neutralisation test; WNV: West Nile virus.

<100 (IgM, IgG): no antibodies detectable at starting serum dilution of 1:100. <20 (NT): no antibodies detectable at starting serum dilution of 1:20.

retrospective analysis of human WNV infections in Austria. Single serum samples from each patient were tested using WNV IgM ELISA as a first qualitative screen. Of these, two were IgM-positive, suggesting possible recent WNV infections. For 82 of the 110 patients, there was sufficient serum available for PCR testing (and for 35 of the 82, CSF was also available): all 85 sera and 35 CSF samples were PCR-negative. This included serum and CSF of the two WNV IgM-positive patients (Cases 1 and 2).

We also tested an additional sample (Case 3), even though it did not meet our selection criteria due to the young age of the patient. During initial tests in 2009, this sample (from an adolescent hospitalised with febrile infection) had shown titre rises in haemagglutination-inhibition assays with various flavivirus antigens, including WNV; however, the result was not verified at that time, because both PCR and WNV IgM ELISA were negative.

Information on the clinical picture, follow-up samples and other relevant available data of these three patients are summarised in the Table. 


\section{FIGURE 3}

Quantitative flavivirus IgM ELISA with sera obtained upon hospitalisation (day 0) of human cases of West Nile virus infection, Austria, 2009-10 ( $\mathrm{n}=3)$ and control sera ${ }^{\mathrm{a}}$
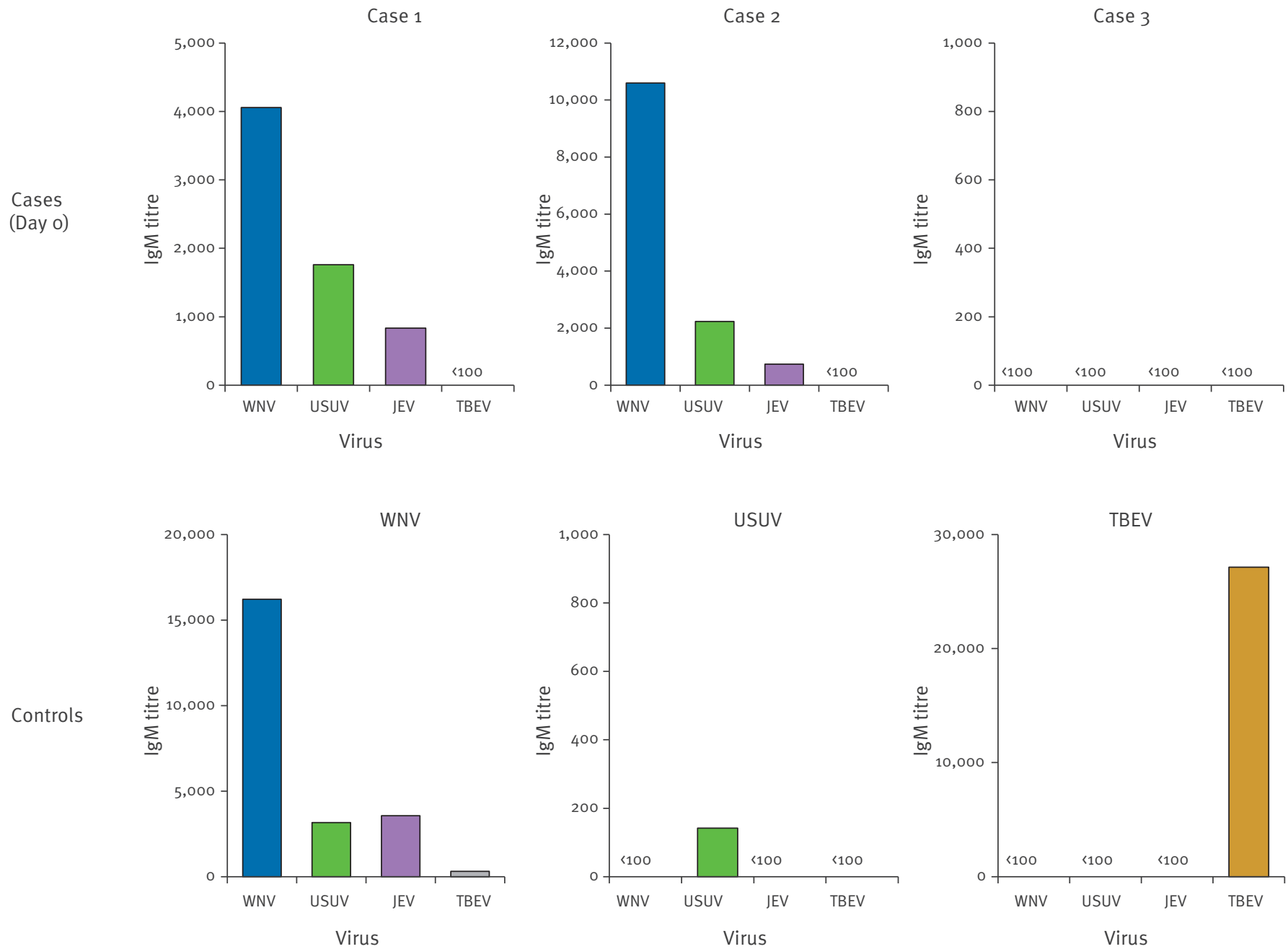

ELISA: enzyme-linked immunosorbent assay; JEV: Japanese encephalitis virus; TBEV: tick-borne encephalitis virus; USUV: Usutu virus; WNV: West Nile virus.

(100: no antibodies detectable at starting serum dilution of 1:100.

a Sera from WNV-, USUV- and TBEV-infected people.

To confirm these three putative WNV infections, we conducted further WNV-specific analyses of initial and follow-up samples, including quantitative IgM and IgG assays, IgG avidity assays and virus NTs (Figure 2). Case 1 had not only IgM on hospitalisation, but also high levels of IgG antibodies, which had decreased in a follow-up sample taken about 2.5 years later. The initial IgG avidity was low but was much higher in the second sample, which was also positive in the WNV NT. For Case 2, only the initial sample was available, containing both IgM as well as low-avidity Ig $G$ antibodies and displaying WNV neutralising activity. Both of these cases thus met the laboratory criteria of the European Union (EU) definition for West Nile fever [21]. Case 3 was IgM-negative both in the initial sample as well as in follow-up samples taken 83 and 111 days later.
In contrast, IgG antibodies (not detectable in the first sample) were found in the two follow-up samples. The titres of these antibodies decreased from day 83 to day 111 , whereas their avidity increased in this period, and both samples were NT-positive. Taken together these data are consistent with a recent infection caused by WNV or a closely related virus in all three cases.

To rule out possible misinterpretations due to crossreactivity, we performed ELISAs with WNV, USUV, JEV and TBEV under standardised conditions that allowed quantitative comparisons of antibody reactivities. The data obtained with serum samples of the three cases and control sera are summarised in Figure 3 (IgM of initial sera) and Figure 4 (IgG of initial and follow-up samples). Except for Case 3 (with no detectable IgM 


\section{FIGURE 4}

Quantitative flavivirus IgG ELISA with sera obtained upon hospitalisation (day 0) and follow-up samples of human cases of West Nile virus infection, Austria, 2009-10 $(n=3)$ and control sera ${ }^{a}$
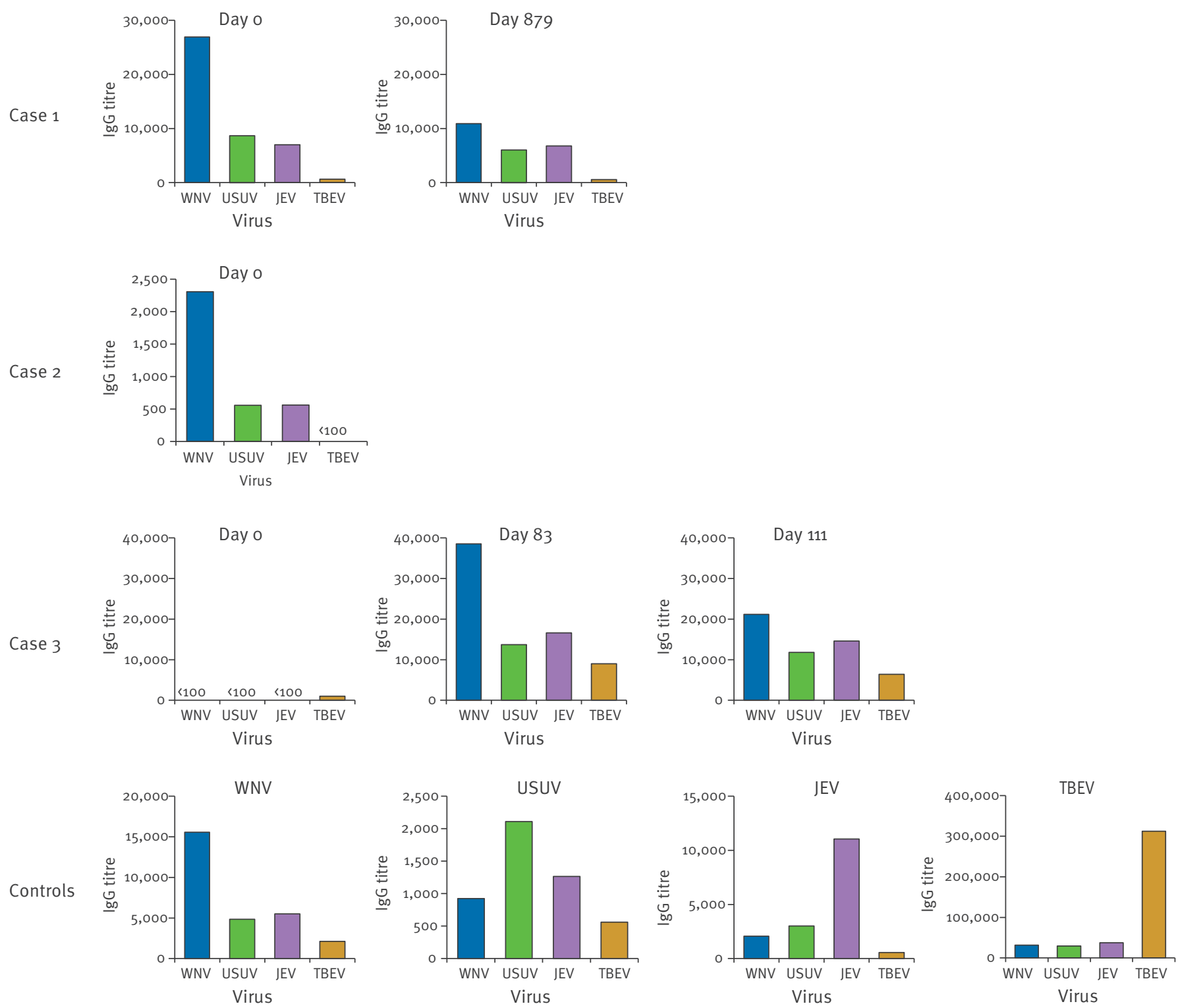

ELISA: enzyme-linked immunosorbent assay; JEV: Japanese encephalitis virus; TBEV: tick-borne encephalitis virus; USUV: Usutu virus; WNV: West Nile virus.

«100: No antibodies detectable at starting serum dilution of 1:100.

a Sera from WNV-, USUV- and TBEV-infected people.

antibodies), the cross-reactive IgM patterns of Cases 1 and 2 were similar to that of the WNV control serum and different from those of the USUV and TBEV control sera, i.e. they displayed much higher titres against WNV than against USUV and TBEV. TBEV-cross-reactive antibodies were not detectable in these samples and the TBEV IgM-positive serum did not cross-react in the WNV assay (Figure 3). Similar quantitative differences were also observed in the IgG assays (Figure 4), which in all three cases - like the WNV control serum - always showed the highest reactivity with WNV and thus differed substantially from the patterns obtained with the USUV, JEV and TBEV control sera. It is important to note that the specificity of the IgG ELISA results diminished over time (Cases 1 and 3; Figure 4) and was most prominent in early serum samples. Taken together, these analyses allowed the identification of recent WNV infections in all three cases. This is especially noteworthy with respect to Case 3: the patient's initial sample had neither WNV IgM nor IgG antibodies but only TBEV IgG antibodies due to vaccination. Since none of the patients had a travel history within 


\section{FIGURE 5}

Place of residence of human cases and location of birds with West Nile virus infection, Austria, 2009-10 $(n=3)$

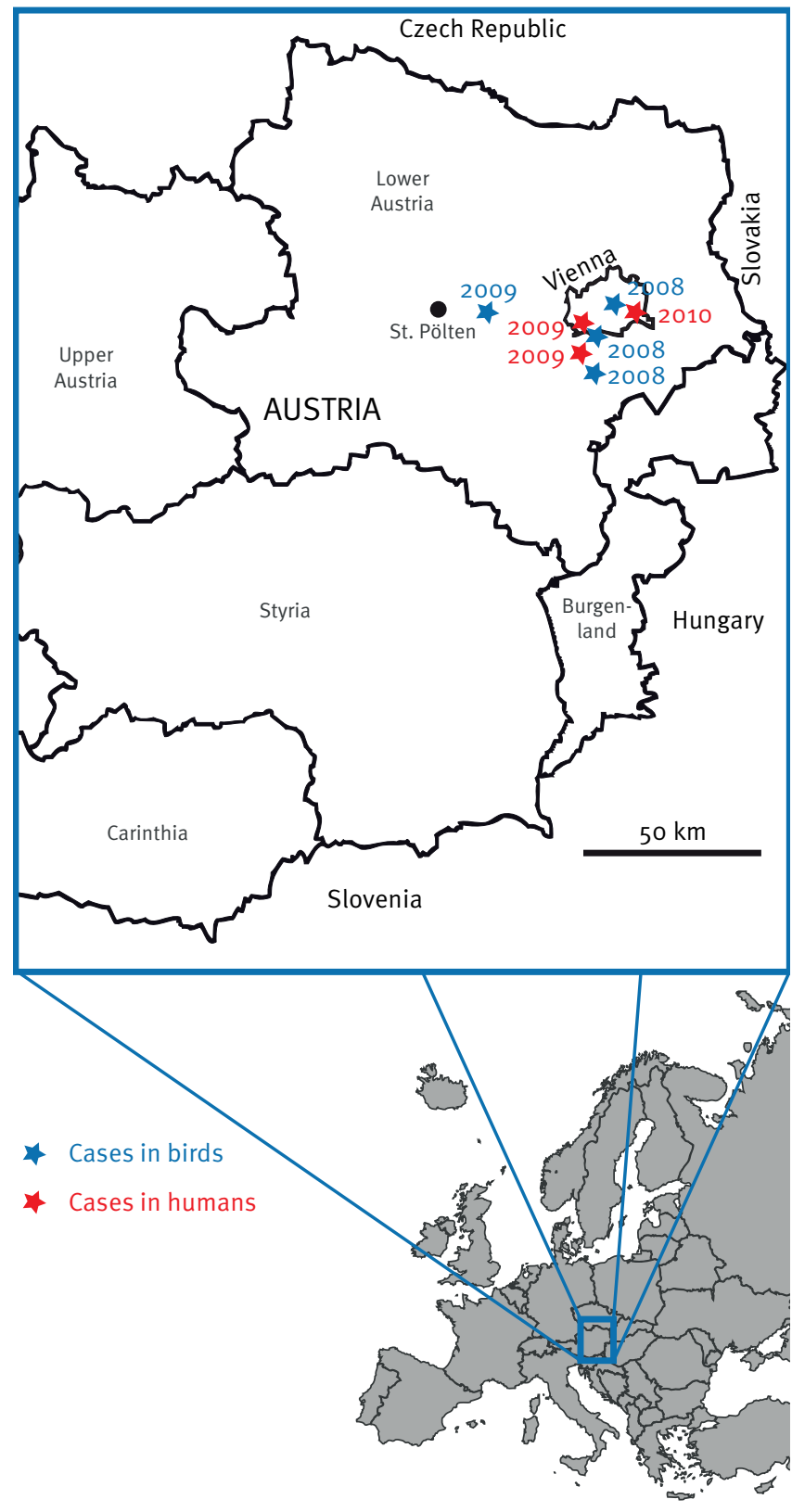

The place of residence of the three patients are indicated in red and the geographical locations of virus isolation from birds with lethal West Nile virus infections in blue [14], together with the year of infection.

the WNV incubation period (Table), these cases were apparently caused by autochthonous WNV infections in Vienna or its surroundings. The place of residence of the three cases matches the locations of previously reported WNV isolations from birds [14] (Figure 5) and/ or mosquitoes (Norbert Nowotny, personal communication, September 2012).

\section{Discussion and conclusions}

Our study was prompted by increasing evidence for WNV infections in Europe and led to the retrospective identification of three human cases of WNV infection in Austria that were probably autochthonous. The putative sites of infection were in Vienna and its surroundings and matched the locations of previously reported WNV isolation from birds and/ or mosquitoes. Consistent with the short viraemia in most of the documented human cases [10] and data from other studies [9], we were unable to detect the virus in serum and/ or CSF samples taken at the time of hospitalisation, and therefore we cannot make any statements on the genetic lineage of WNV that caused these infections. Lineage 2 viruses, however, are the more likely candidates, because these were isolated from birds in the same geographical area in 2008 and 2009, whereas lineage 1 viruses have not yet been detected in Austria.

In addition to WNV, the closely related USUV also emerged in central and southern Europe, following its first detection outside Africa in Austria in 2001 [7,8]. This virus cross-reacts with WNV in serological assays, including virus NTs [12]. Since the initial samples of all three patients with suspected WNV infection were PCRnegative, we established serological assays (based on inactivated purified virions) that allowed the differentiation between infections with WNV and USUV as well as other closely related flaviviruses. As expected, these assays displayed strong cross-reactivities between WNV and USUV (and JEV, another member of the same flavivirus serocomplex), not only in IgG but also in IgM assays. Only the comparison of the patterns obtained in quantitative and standardised immunoassays allowed a clear distinction between these infections. Our study thus points to the important fact that the serological differentiation between WNV, USUV and other viruses of the same flavivirus serocomplex requires comparative quantitative in addition to qualitative serological analyses, even when the NT (usually considered the most discriminating assay [22]) is positive.

Of all European countries, Austria has the highest seroprevalence of antibodies to TBEV because about $85 \%$ of its population has been vaccinated against it at least once [11]. Since TBEV and WNV infections both display very similar clinical pictures, distinguishing between WNV and TBEV antibodies will be frequently required in routine diagnostic practice. The present and previous studies of our group [23] as well as others [24], however, indicate that the extent of cross-reactivity between the two viruses - especially in IgM assays is so low that distinguishing between recent infections is usually unproblematic.

Somewhat unexpectedly, one of our three cases (Case 3) had no measurable WNV-specific IgM antibodies, neither in the sample taken at symptom onset nor 83 and 111 days later, and would therefore not meet the EU case definition for West Nile fever [21]. All other parameters, however, were consistent with a recent 
WNV infection, including IgG seroconversion, increase of IgG avidity, WNV-specific NT and the reactivity patterns with USUV, JEV and TBEV. One possible interpretation would be that the first serum sample was taken before the onset of the antibody response and that IgM antibodies produced later on had already declined to non-detectable levels after 83 days. Consistent with the vaccination history, this patient had TBEV-reactive IgG antibodies at the time of symptom onset, which increased in the course of the WNV infection, presumably due to the boosting and/or new induction of cross-reactive antibodies (Figure 4). To what extent the immunity against TBEV might have contributed to a low and/or delayed WNV-specific IgM response remains unresolved and a matter of speculation.

Considering that our search criteria were restricted to people over 70 years of age (about $13 \%$ of the total population in Austria) [25] and that only less than $1 \%$ of infections $(1 / 150)$ progress to severe CNS symptoms $[10,22]$, it is justified to assume that the real number of infections in the east of Austria was at least in the range of several hundred in the study years. Our data are consistent with recent findings of increasing WNV antibody titres in human plasma collected in Austria, Germany and the Czech Republic from 2006 to 2010 [26] and support activities to increase vigilance for this infection as a potential public health problem in central Europe [27]. In this context, it is also important to strengthen the awareness of clinicians for WNV infections, especially during the summer months, and to include tests for WNV into routine diagnostic practice of CNS diseases.

\section{Acknowledgements}

We thank Cornelia Stoeckl, Jutta Hutecek, Barbara Dalmatiner and Walter Holzer for excellent technical assistance.

\section{Conflict of interest}

None declared.

\section{Authors' contributions}

KS, SWA and FXH conceived and designed the experiments. KS and SWA performed the experiments. KS, FXH and SWA analysed the data. FXH, KS and SWA wrote the paper.
References

1. Simmonds P, Becher P, Collett MS, Gould EA, Heinz FX, Meyers G, et al. Family Flaviviridae. In: King AMQ, Lefkowitz E, Adams MJ, Carstens EB, editors. Virus taxonomy. Ninth report of the International Committee on Taxonomy of Viruses. San Diego, CA: Elsevier Academic Press; 2011. p. 1003-20.

2. Reiter P. West Nile virus in Europe: understanding the present to gauge the future. Euro Surveill. 2010;15(10):pii=19508. Available from: http://www.eurosurveillance.org/ViewArticle. aspx?Articleld $=19508$

3. Pierson TC, Diamond MS. Flaviviruses. In: Knipe DM, Howley PM, Cohen II, Griffin DE, Lamb RA, Martin MA, et al., editors. Fields virology. 6 ed. Philadelphia: Lippincott Williams \& Wilkins; 2013. p. 747-94.

4. Calistri P, Giovannini A, Hubalek Z, Ionescu A, Monaco F, Savini G, et al. Epidemiology of West Nile in Europe and in the Mediterranean Basin. Open Virol J. 2010;4:29-37. http://dx.doi. org/10.2174/1874357901004010029. http://dx.doi.org/10.2174/ 1874357901004020029.

PMid:20517490. PMCid:PMC2878979.

5. European Centre for Disease Prevention and Control (ECDC). West Nile fever maps. Stockholm: ECDC; 2012. [Accessed 10 October 2013]. Available from: http://ecdc.europa.eu/en/ healthtopics/west_nile_fever/West-Nile-fever-maps/Pages/ index.aspx

6. Danis K, Papa A, Theocharopoulos G, Dougas G, Athanasiou $M$, Detsis $M$, et al. Outbreak of West Nile virus infection in Greece, 2010. Emerg Infect Dis. 2011;17(10):1868-72. http://dx.doi.org/10.3201/eid1710.110525. PMid:22000357. PMCid:PMC3310677.

7. Weissenböck H, Kolodziejek J, Url A, Lussy H, Rebel-Bauder B, Nowotny N. Emergence of Usutu virus, an African mosquitoborne flavivirus of the Japanese encephalitis virus group, central Europe. Emerg Infect Dis. 2002;8(7):652-6. http:// dx.doi.org/10.3201/eido807.020094. PMid:12095429. PMCid:PMC 2730324.

8. Vazquez A, Jimenez-Clavero M, Franco L, Donoso-Mantke 0 , Sambri V, Niedrig M, et al. Usutu virus: potential risk of human disease in Europe. Euro Surveill. 2011;16(31):pii=19935. Available from: http://www.eurosurveillance.org/ViewArticle. aspx?Articleld $=19935$

9. Papa A, Danis K, Baka A, Bakas A, Dougas G, Lytras T, et al. Ongoing outbreak of West Nile virus infections in humans in Greece, July-August 2010. Euro Surveill. 2010;15(34):pii=19644. Available from: http://www. eurosurveillance.org/ViewArticle.aspx?Articleld=19644. PMid:20807489.

10. Dauphin G, Zientara S. West Nile virus: recent trends in diagnosis and vaccine development. Vaccine. 2007;25(30):5563-76. http://dx.doi.org/10.1016/j.vaccine.2006.12.005 PMid:17292514.

11. Heinz FX, Stiasny K, Holzmann H, Grgic-Vitek M, Kriz B, Essl A, et al. Vaccination and tick-borne encephalitis, central Europe. Emerg Infect Dis. 2013;19(1):69-76. http://dx.doi.org/10.3201/ eid1901.120458. PMid:23259984. PMCid:PMC3557984.

12. Calisher CH, Karabatsos N, Dalrymple JM, Shope RE, Porterfield JS, Westaway EG, et al. Antigenic relationships between flaviviruses as determined by cross-neutralization tests with polyclonal antisera. J Gen Virol. 1989;70 (Pt 1):37-43. http://dx.doi.org/10.1099/0022-1317-70-1-37. PMid:2543738.

13. Kuno G. Serodiagnosis of flaviviral infections and vaccinations in humans. Adv Virus Res. 2003;61:3-65. http://dx.doi. org/10.1016/So065-3527(03)61001-8

14. Wodak E, Richter S, Bagó Z, Revilla-Fernández S, Weissenböck $\mathrm{H}$, Nowotny N, et al. Detection and molecular analysis of West Nile virus infections in birds of prey in the eastern part of Austria in 2008 and 2009. Vet Microbiol. 2011;149(3 4):358-66. http://dx.doi.org/10.1016/j.vetmic.2010.12.012. PMid:21276665.

15. Zeller HG, Schuffenecker I. West Nile virus: an overview of its spread in Europe and the Mediterranean basin in contrast to its spread in the Americas. Eur J Clin Microbiol Infect Dis. 2004;23(3):147-56. http://dx.doi.org/10.1007/s10096-0031085-1. PMid:14986160.

16. Stiasny K, Kiermayr S, Holzmann H, Heinz FX. Cryptic properties of a cluster of dominant flavivirus crossreactive antigenic sites. J Virol. 2006;80(19):9557-68. http://dx.doi.org/10.1128/JVI.00080-06. PMid:16973559. PMCid:PMC1617264.

17. Zlatkovic J, Stiasny K, Heinz FX. Immunodominance and functional activities of antibody responses to inactivated West Nile virus and recombinant subunit vaccines in mice. J Virol. 2011;85(5):1994-2003. http://dx.doi.org/10.1128/JVI.01886-10. PMid:21147919. PMCid:PMC3067796. 
18. Stiasny K, Holzmann H, Heinz FX. Characteristics of antibody responses in tick-borne encephalitis vaccination breakthroughs. Vaccine. 2009;27(50):7021-6. http://dx.doi. org/10.1016/j.vaccine.2009.09.069. PMid:19789092.

19. Tang Y, Anne Hapip C, Liu B, Fang CT. Highly sensitive TaqMan RT-PCR assay for detection and quantification of both lineages of West Nile virus RNA. J Clin Virol. 2006;36(3):177-82. http:// dx.doi.org/10.1016/j.jcv.2006.02.008. PMid:16675298.

20. Linke S, Mackay WG, Scott C, Wallace P, Niedrig M. Second external quality assessment of the molecular diagnostic of West Nile virus: are there improvements towards the detection of WNV? J Clin Virol. 2011;52(3):257-60. http://dx.doi. org/10.1016/j.jcv.2011.08.010. PMid:21893429.

21. European Commission (EC). West Nile fever. Commission decision of $28 /$ IV/2008 amending Decision 2002/253/EC laying down case definitions for reporting communicable diseases to the Community network under Decision No 2119/98/EC of the European Parliament and of the Council. Luxembourg: Publications Office of the European Union; 2008. p. 76-7. [Accessed 15 Oct 2013]. Available from: http://ec.europa.eu/ health/ph_threats/com/docs/1589_2008_en.pdf

22. De Filette $M$, Ulbert S, Diamond M, Sanders NN. Recent progress in West Nile virus diagnosis and vaccination. Vet Res. 2012;43(1):16.

http://dx.doi.org/10.1186/1297-9716-43-16. PMid:22380523. PMCid:PMC3311072.

23. Stiasny K, Aberle JH, Chmelik V, Karrer U, Holzmann H, Heinz FX. Quantitative determination of IgM antibodies reduces the pitfalls in the serodiagnosis of tick-borne encephalitis. J Clin Virol. 2012;54(2):115-20. http://dx.doi.org/10.1016/j. jcv.2012.02.016. PMid:22421535.

24. Papa A, Karabaxoglou D, Kansouzidou A. Acute West Nile virus neuroinvasive infections: cross-reactivity with dengue virus and tick-borne encephalitis virus. J Med Virol. 2011;83(10):1861-5. http://dx.doi.org/10.1002/jmv.22180. PMid:21837806.

25. Statistik Austria. Bevölkerungsstand 1.1. 2012. [Population structure 1.1. 2012]. Vienna: Statistik Austria; Aug 2012. [Accessed 7 Oct 2013]. German. Available from: http://www. statistik.at/web_de/services/publikationen/2/index.html

26. Rabel PO, Planitzer CB, Farcet MR, Orlinger KK, Ilk R, Barrett $P N$, et al. Increasing West Nile virus antibody titres in central European plasma donors from 2006 to 2010. Euro Surveill. 2011;16(10):pii=19812. Available from: http://www. eurosurveillance.org/ViewArticle.aspx?Articleld=19812. PMid:21435324.

27. Zeller H, Lenglet $A$, Van Bortel W. West Nile virus: the need to strengthen preparedness in Europe. Euro Surveill. 2010;15(34): pii=19647. Available from: http://www. eurosurveillance.org/ViewArticle.aspx?Articleld=19647 